\title{
A terápiás apheresisek számának és indikációjának változása, valamint új eljárások megjelenése Magyarországon 2013 és 2017 között
}

\author{
Soltész Pál dr.* \\ Debreceni Egyetem, Klinikai Központ, Belgyógyászati Klinika C épület, \\ Intenzív Osztály és Terápiás Aferezis Részleg, Debrecen
}

\begin{abstract}
A terápiás apheresis több szakmát érintő kezelési lehetőség. Viszonylag drága beavatkozásról van szó, melyet csak kijelölt centrumok végezhetnek az adott indikációk alapján. A kezelés eseti finanszírozásban részesül, a Terápiás Aferezis Bizottság és a Nemzeti Egészségbiztosítási Alapkezelő közösen ellenőrzi az elvégezhető beavatkozások számát, az új diagnózisok bevezetését, illetve új apheresiseljárások magyarországi engedélyezését. Ebben a munkában a 2013 és 2017 közötti időszak hazai apheresisterápiás gyakorlatát tekintjük át, ismertetve a bevezetés alatt álló új eljárásokat is. Orv Hetil. 2019; 160(19): 727-738.
\end{abstract}

Kulcsszavak: terápiás apheresis, magyarországi adatok, ajánlások, új módszerek

\begin{abstract}
National survey of the therapeutic apheresis in Hungary, 2013-2017
Therapeutic apheresis is a treatment option for several subspecialities. It is a relatively expensive intervention, which can only be done by dedicated centers based on specific indications. The Therapeutic Apheresis Committee and the National Health Insurance Fund of Hungary jointly control the number of interventions to be made, the introduction of new diagnoses and the application of new apheresis procedures in Hungary. In this work, we review the therapeutic practice of the period between 2013 and 2017 in Hungary, describing also the new modalities under implementation.
\end{abstract}

Keywords: therapeutic apheresis, national survey in Hungary, recommendations, new procedures

Soltész P. [National survey of the therapeutic apheresis in Hungary, 2013-2017]. Orv Hetil. 2019; 160(19): 727738 .

(Beérkezett: 2018. november 26.; elfogadva: 2019. február 2.)

\begin{abstract}
Rövidítések
$\mathrm{AB} 0=$ vércsoportrendszer; $\mathrm{ADAMTS} 13=\mathrm{a}$ disintegrin and metalloproteinase with a thrombospondin type 1 motif, member $13 ; \mathrm{AMD}=$ (age-related macular degeneration) időskori maculadegeneratio; $\mathrm{ANCA}=$ antineutrophil cytoplasmaticus antitest; CIDP $=$ (chronic inflammatory demyelinating polyneuropathy) krónikus inflammatoricus demyelinisatiós polyneuropathia; DALI $=($ direct adsorption of lipoproteins $)$ lipoproteinek direkt adszorpciója; GVHD $=$ (graft versus host
\end{abstract}

disease) graft versus host betegség; HBV = hepatitis B-vírus; HELLP-szindróma $=$ (hemolysis, elevated liver enzymes, low platelet count syndrome) vörösvértestek szétesésével, emelkedett májenzimszinttel és alacsony vérlemezkeszinttel járó szindróma; HELP = (heparin-induced extracorporeal lipoprotein precipitation) heparin indukálta extracorporalis lipoproteinprecipitáció; HUS = (hemolytic uremic syndrome $)$ haemolyticus uraemiás szindróma; $\mathrm{LDL}=$ (low-density lipoprotein $)$ alacsony sűrúségű lipoprotein; MONET = (membrane filtrati- 
on extracorporeal treatment) membránfiltrációs extracorporalis kezelés; NEAK = Nemzeti Egészségbiztosítási Alapkezelő; $\mathrm{TTP}=($ thrombotic thrombocytopenic purpura) thromboticus thrombocytopeniás purpura

Az apheresis patológiás vérkomponens(ek) eltávolítására alkalmas extracorporalis eljárás, mely a jelenlegi indikációk alapján közel 100 betegség kezelésében alkalmazott terápia, a neurológiai betegségektól kezdve a hematológiai és nefrológiai indikációkon át egészen a mérgezésekig. Az indikációra vonatkozó klinikai kutatások az 1950-es években egybeestek a modern sejtszeparátorok fejlesztésével, majd a szelektív filter- és oszloptechnikák megalkotásával. Ez lehetővé tette, hogy sejtes vonatkozásban és egyes plasmakomponensekkel kapcsolatban kialakuljanak azok a szelektív és nemszelektív modalitások, amelyek napjainkban az apheresisterápia igen széles körü alkalmazását teszik lehetôvé. A plasma, a thrombocyta, a fehérvérsejt és a vörösvértest szelektív eltávolításán túl kifejlesztették azokat a speciális kaszkádrendszereket, amelyek a plasmaszeparálást követő második lépésben alkalmasak speciális fehérjék, például immunglobulinok, lipidfrakciók, illetve citokinek eltávolítására. A jelenlegi ajánlásokban [1] a következő terápiás modalitások jelennek meg: plasmapheresis/plasmacsere (therapeutical plasma exchange), erythrocytapheresis, leukocytapheresis, lymphocytapheresis, granulocytapheresis, thrombocytapheresis, valamint LDL-apheresis, rheopheresis, immunadszorpció és fotopheresis. A jelenleg nemzetközileg elfogadott indikációs listát az 1. táblázat mutatja be.

A magyarországi apheresiskezelések adatait legutóbb Jákó és mtsa [2] foglalták össze, akik a 2001 és 2004 között végzett plasmacsere- és cytapheresiskezeléseket elemezték, majd 2012-ben a 2001 és 2010 közötti időszak plasmapheresiseinek teljes összefoglalója jelent meg [3]. Domján és mtsai [4] 2012-ben összefoglalták a felnőttkori indikációkat, valamint Túri és mtsai a gyermekkori kezelési lehetőségeket [5]. Réti Marienn a thromboticus thrombocytopeniás purpura és a haemolyticus uraemiás szindróma kapcsán készített összefoglalót [6], munkacsoportunk pedig a debreceni III. sz. Belklinika 30 éves apheresistevékenységét foglalta össze [7]. Tekintettel az indikációk változására és az új típusú kezelések bevezetésére, indokoltnak túnik, hogy újra áttekintsük a magyarországi helyzetet; ehhez a 2013 és 2017 közötti hazai apheresiskezelések adatait dolgoztam fel, melyeket a NEAK Speciális Finanszírozási Főosztálya bocsátott rendelkezésemre.

\section{A 2013 és 2017 közötti időszak magyarországi apheresistevékenységének áttekintése}

Nézzük először, hogyan épül fel a magyarországi apheresisellátás szerkezete. Magyarországon jelenleg 23 centrumban végeznek plasmapheresis-kezelést, valamint
3 centrumban photopheresiskezelést (Dél-pesti Centrumkórház - Országos Hematológiai és Infektológiai Intézet; Debreceni Egyetem, Klinikai Központ; Semmelweis Egyetem, Budapest). A kezelési számokat, illetve új centrumok kialakítását az Országos Terápiás Aferezis Bizottság koordinálja szakmailag, és a NEAK Speciális Finanszírozási Fôosztályával szorosan együttmúk ödve biztosítják azt a szakmai és finanszírozási feltételrendszert, amelyben a Magyarországon szükségessé váló apheresiskezelések ez idáig hiánytalanul elvégezhetôk voltak. Külön ki kell emelni a HAEMOBIL Kft. szerepét, amely mozgó apheresisközpontként végez kezeléseket azon kórházakban, ahol nem múködik terápiás apheresisközpont. Látható, hogy drága beavatkozásról van szó, mely egyedi finanszírozási csoportba tartozik. A jelenlegi NEAK által biztosított finanszírozási összeg plasmapheresis esetén $236500 \mathrm{Ft} /$ kezelés, míg photopheresis esetében $341000 \mathrm{Ft} /$ kezelés. A 2017. finanszírozási évet figyelembe véve összességében 5762 kezelést végeztünk, ami 1466300000 Ft összköltséget jelent. A részletes adatokat a 2. táblázatban tüntettük fel.

A centrumok kezelési számából látható, hogy eltérő nagyságrendú kezelések történnek, és bizonyos specializálódó tendenciák is vannak. A szakmai törekvés az, hogy amennyiben új centrum nýlik, az alkalmas legyen a területileg illetékes sürgősségi apheresisellátásra.

A következőkben az ezen centrumok által végzett és a NEAK felé eseti finanszírozott adatlapon eljuttatott diagnózisokkal foglalkozunk a 2013 és 2017 közötti időszakot áttekintve. A 3. táblázatban látható, hogy ebben a periódusban a kezelési számok fluktuáltak, és összességében $\mathrm{kb}$. 300 kezelésiszám-növekedést tapasztaltunk (5488-5859-5766-5577-5762).

Ha a fenti diagnózisokat elemezzük az 5 éves periódusban történó változások alapján, akkor az alábbi megállapítások tehetôk.

A Guillain-Barré-szindróma éves kezelési száma stabilnak mondható. Az említett öt évben 748-775-696660-720 eset. Ezzel szemben a CIDP folyamatos emelkedést mutat (302-387-399-425-561), ami 85\%-os ötéves növekedést jelent. Az adott öt évet tekintve érdekes, hogy a myasthenia gravis és a Guillain-Barré-szindróma miatti kezelések éves fluktuációja nagyon hasonló; a myasthenia gravis miatt kezelt betegek száma évenkénti bontásban: 718-704-636-559-656 (1. ábra).

A TTP + HUS kezelési száma folyamatosan csökkent. A 2014-es 580 kezelés 2015-ben 500-ra, majd 2016ban 420-ra, végül 2017-ben már 400 alá, 388-ra csökkent.

Az ANCA-asszociált és egyéb vasculitisek, mint a polyarteritis nodosa, illetve a cryoglobulinaemiás vasculitisek miatt végzett kezelési számok magasak: 2013-tól 2016-ig meghaladták az évi 300-at.

Az apheresiskeretből egyre nagyobb hányad kerül felhasználásra a transzplantációval kapcsolatos indikációk elvégzésére. Ez plasmapheresisre és photopheresisre egyaránt igaz. A csontvelő-transzplantációt követő 
1. táblázat |Az apheresisek indikációi és az indikációk erőssége a jelenlegi nemzetközi ajánlások alapján

\begin{tabular}{|c|c|c|}
\hline \multicolumn{3}{|c|}{ Plasmapheresis } \\
\hline Kategória & Betegségek & Indikációk \\
\hline \multirow{23}{*}{$\begin{array}{l}\text { I. Első vonalbeli } \\
\text { ajánlás }\end{array}$} & Guillain-Barré-szindróma & Primer terápia \\
\hline & Akut májelégtelenség (nagy volumenú plasmapheresis) & \\
\hline & \multirow[t]{2}{*}{ ANCA-asszociált rapidan progrediáló glomerulonephritis } & Dialízisdependens \\
\hline & & Diffúz alveolaris haemorrhagia \\
\hline & \multirow[t]{2}{*}{ Antiglomerularis basalis membrán betegség (Goodpasture-szindróma) } & Diffúz alveolaris haemorrhagia \\
\hline & & Dialízisindependens \\
\hline & \multicolumn{2}{|l|}{ Krónikus inflammatoricus demyelinisatiós polyradiculoneuropathia } \\
\hline & \multirow[t]{2}{*}{ Monoclonalis gammopathia hiperviszkozitással } & Tüneti kezelés \\
\hline & & Rituximabprofilaxis \\
\hline & Májtranszplantáció & $\begin{array}{l}\text { Deszenzitizáció, } \\
\text { AB0-inkompatibilitás }\end{array}$ \\
\hline & \multirow[t]{2}{*}{ Myasthenia gravis } & Középsúlyos \\
\hline & & Thymectomiát megelőzően \\
\hline & \multicolumn{2}{|l|}{ N-metil-D-aszpartát-receptor-ellenes antitest közvetítette encephalitis } \\
\hline & \multirow{2}{*}{$\begin{array}{l}\text { Paraproteinaemiás demyelinisatiós neuropathia/krónikus, szerzett } \\
\text { demyelinisatiós polyneuropathia }\end{array}$} & $\operatorname{IgG} / \operatorname{IgA}$ \\
\hline & & $\operatorname{IgM}$ \\
\hline & \multicolumn{2}{|l|}{ Natalizumabasszociált progresszív multifocalis leukoencephalopathia } \\
\hline & \multirow[t]{2}{*}{ Vesetraszplantáció, AB0-kompatibilis } & Antitest mediálta rejekció \\
\hline & & Deszenzitizáció \\
\hline & Vesetraszplantáció, AB0-inkompatibilis & Deszenzitizáció \\
\hline & Thromboticus microangiopathia, komplementmediált & H-faktor-autoantitestek \\
\hline & Thromboticus microangiopathia, gyógyszerrel összefüggő & Tiklopidin \\
\hline & \multicolumn{2}{|l|}{ Thromboticus thrombocytopeniás purpura } \\
\hline & Wilson-kór & Fulmináns \\
\hline \multirow{17}{*}{$\begin{array}{l}\text { II. Második } \\
\text { vonalbeli } \\
\text { ajánlás }\end{array}$} & Akut disszeminált encephalomyelitis & Szteroidrefrakter \\
\hline & Autoimmun haemoliticus anaemia; WAHA; hidegagglutinin-betegség & Súlyos hidegagglutinin-betegség \\
\hline & Szívtranszplantáció & Deszenzitizáció \\
\hline & \multicolumn{2}{|l|}{ Katasztrofális antifoszfolipidszindróma } \\
\hline & Cryoglobulinaemia & Tünetekkel/súlyos \\
\hline & Familiaris hypercholesterinaemia & Homozigóta, heterozigóta \\
\hline & $\begin{array}{l}\text { Hashimoto-encephalopathia: autoimmun thyroiditisszel összefüggő, } \\
\text { szteroidra reagáló encephalopathia }\end{array}$ & \\
\hline & \multicolumn{2}{|l|}{ Lambert-Eaton-szindróma } \\
\hline & Multiplex sclerosis & $\begin{array}{l}\text { Akut központi idegrendszeri inflammatoricus } \\
\text { demyelinisatio }\end{array}$ \\
\hline & \multicolumn{2}{|l|}{ Myeloma okozta neuropathia } \\
\hline & Neuromyelitis optica spektrumbetegségek & Akut \\
\hline & \multicolumn{2}{|l|}{ Gombamérgezések } \\
\hline & $\begin{array}{l}\text { Gyermekgyógyászati autoimmun neuropszichiátriai rendellenességek } \\
\text { Streptococcus-fertőzéssel összefüggésben }\end{array}$ & Exacerbatio \\
\hline & \multicolumn{2}{|l|}{ Refsum-kór } \\
\hline & Vesetranszplantáció, AB0-inkompatibilis & Antitest mediálta rejekció \\
\hline & Szisztémás lupus erythematosus & Súlyos \\
\hline & Polyarteritis nodosa & HBV-asszociált \\
\hline
\end{tabular}




\section{1. táblázat folyt.}

\begin{tabular}{|c|c|c|}
\hline \multicolumn{3}{|c|}{ Plasmapheresis } \\
\hline Kategória & Betegségek & Indikációk \\
\hline \multirow{42}{*}{$\begin{array}{l}\text { III. Egyéni } \\
\text { megítélés } \\
\text { alapján } \\
\text { végzett } \\
\text { kezelés }\end{array}$} & Guillain-Barré-szindróma & IVIG után \\
\hline & Akut májelégtelenség & \\
\hline & ANCA-asszociált rapidan progrediáló glomerulonephritis & Dialízisindependens \\
\hline & Antiglomerularis basalis membrán betegség (Goodpasture-szindróma) & $\begin{array}{l}\text { Dialízisdependens, diffúz alveolaris } \\
\text { haemorrhagia nélkül }\end{array}$ \\
\hline & Aplasticus anaemia, tiszta vörösvértest-aplasia & \\
\hline & Atopiás dermatitis & \\
\hline & Autoimmun haemoliticus anaemia; WAHA & Súlyos meleg AHA \\
\hline & Égési sokk & \\
\hline & Cardialis neonatalis lupus & \\
\hline & Szívtranszplantáció & Antitest mediálta rejekció \\
\hline & Krónikus focalis encephalitis & \\
\hline & Koagulációsfaktor-inhibitorok & Autoantitest \\
\hline & Dilatatív cardiomyopathia, idiopathiás & NYHA II-IV. \\
\hline & Erythropoeticus porphyria & \\
\hline & HELLP-szindróma & Post partum \\
\hline & Haemopoeticusőssejt-transzplantáció, HLA-deszenzitizáció & \\
\hline & $\begin{array}{l}\text { Haemophagocytás lymphohistiocytosis; haemophagocytaszindróma; } \\
\text { makrofágaktivációs szindróma }\end{array}$ & \\
\hline & Henoch-Schönlein-purpura & Súlyosbodó, súlyos extrarenalis társuló tünet \\
\hline & Heparinindukált thrombocytopenia és thrombosis & Cardiopulmonalis bypass előtt \\
\hline & Hypertriglyceridaemiás pancreatitis & \\
\hline & Immunthrombocytopenia & Terápiarezisztens \\
\hline & IgA-nephropathia & Súlyosbodó \\
\hline & & Krónikus progresszív \\
\hline & Májtranszplantáció & Deszenzitizáció, AB0-inkompatibilis \\
\hline & & $\begin{array}{l}\text { Antitest mediálta rejekció } \\
\text { nat }\end{array}$ \\
\hline & Tüdőtranszplantáció & Antitest mediálta rejekció \\
\hline & & Deszenzitizáció \\
\hline & Multiplex sclerosis & Krónikus progresszív \\
\hline & Nephrogen szisztémás fibrosis & \\
\hline & Neuromyelitis optica spektrumbetegségek & Fenntartó kezelés \\
\hline & Mérgezés, gyógyszer-túladagolás & \\
\hline & Paraneoplasiás neurológiai betegségek & \\
\hline & $\begin{array}{l}\text { Paraproteinaemiás demyelinisatiós neuropathia/krónikus, szerzett } \\
\text { demyelinisatiós polyneuropathia }\end{array}$ & $\begin{array}{l}\text { Antimyelinasszociált glikoprotein okozta } \\
\text { neuropathia }\end{array}$ \\
\hline & & Multiplex myeloma \\
\hline & Sydenham-chorea & Súlyos \\
\hline & Pemphigus vulgaris & Súlyos \\
\hline & Poszttranszfúziós purpura & \\
\hline & Hepatobiliaris betegségek okozta viszketés & Terápiarezisztens \\
\hline & Vörösvértest-alloimmunizáció terhességben & Intrauterin transzfúzió előtt \\
\hline & Vesetranszplantáció, AB0-kompatibilis & Deszenzitizáció \\
\hline & Szisztémás sclerosis & \\
\hline & Szepszis többszervi elégtelenséggel & \\
\hline
\end{tabular}




\section{1. táblázat folyt.}

\begin{tabular}{|c|c|c|}
\hline \multicolumn{3}{|c|}{ Plasmapheresis } \\
\hline \multirow[t]{14}{*}{ Kategória } & Betegségek & Indikációk \\
\hline & Stiff-person-szindróma & \\
\hline & Hirtelen sensorineuralis hallásvesztés & \\
\hline & Thromboticus microangiopathia, koagulációmediált & THBD-mutáció \\
\hline & Thromboticus microangiopathia, komplementmediált & Komplementfaktor-génmutációk \\
\hline & & MCP-mutációk \\
\hline & Thromboticus microangiopathia, gyógyszerrel összefüggő & Klopidogrél \\
\hline & & Kalcineurininhibitorok \\
\hline & $\begin{array}{l}\text { Thromboticus microangiopathia, haemopoeticusőssejt-transzplantációval } \\
\text { összefüggő }\end{array}$ & \\
\hline & Thromboticus microangiopathia, Shiga-toxin-mediált & Súlyos neurológiai tünetek \\
\hline & & Streptococcus pneumoniae \\
\hline & Thyreotoxicus krízis & \\
\hline & Toxicus epidermalis necrolysis & Refrakter esetek \\
\hline & Behçet-kór & \\
\hline \multirow{9}{*}{$\begin{array}{l}\text { IV. Hatástalannak } \\
\text { vagy károsnak ítélt } \\
\text { eljárás }\end{array}$} & Szisztémás amyloidosis & \\
\hline & Koagulációsfaktor-inhibitorok & Alloantitest \\
\hline & Dermatomyositis/polymyositis & \\
\hline & HELLP-szindróma & Ante partum \\
\hline & $\begin{array}{l}\text { Paraproteinaemiás demyelinisatiós neuropathia/krónikus szerzett } \\
\text { demyelinisatiós polyneuropathia }\end{array}$ & Multifocalis motoros neuropathia \\
\hline & Psoriasis & \\
\hline & Szisztémás lupus erythematosus & Nephritis \\
\hline & Thromboticus microangiopathia, gyógyszerrel összefüggő & Gemcitabin \\
\hline & & Kinin \\
\hline
\end{tabular}

\begin{tabular}{lll}
\hline & \multicolumn{1}{c}{ Cytapheresisek } \\
\hline Kategóriák & Betegség & Indikációk \\
\hline Erythrocytapheresis & & \\
\hline I. Elsó vonalbeli ajánlás & Herediter haemochromatosis & \\
\cline { 2 - 3 } & Polycythaemia vera & Akut stroke \\
\cline { 2 - 3 } & Sarlósejtes betegség, akut & Stroke-profilaxis \\
\cline { 2 - 3 } & Sarlósejtes betegség, krónikus & Vastúladagolásban prevenció \\
\hline II. Második vonalbeli ajánlás & Babesiosis & Súlyos \\
\cline { 2 - 3 } & Sarlósejtes betegség, akut & Súlyos akutmellkas-szindróma \\
\hline III. Egyéni megítélés alapján végzett kezelés & Erythropoeticus porphyria, májbetegség & Minor haemopoeticus őssejt, apheresis \\
\cline { 2 - 3 } & $\begin{array}{l}\text { Haemopoeticusőssejt-transzplantáció, AB0-in- } \\
\text { kompatibilis }\end{array}$ & Súlyos \\
\cline { 2 - 3 } & Malária & Szekunder \\
\cline { 2 - 3 } & Erythrocytosis &
\end{tabular}


1. táblázat folyt.

\begin{tabular}{|c|c|c|}
\hline \multicolumn{3}{|c|}{ Cytapheresisek } \\
\hline \multirow[t]{8}{*}{ Kategóriák } & Betegség & Indikációk \\
\hline & $\begin{array}{l}\text { Vörösvértest-expozíciót követő RhD-alloimmu- } \\
\text { nizáció-prevenció }\end{array}$ & $\mathrm{RhD}(+)$-vörösvértest-expozíció \\
\hline & \multirow[t]{3}{*}{ Sarlósejtes betegség, akut } & Priapismus \\
\hline & & Multiorgan failure \\
\hline & & $\begin{array}{l}\text { Lép/máj sequestratio; intrahepaticus } \\
\text { cholestasis }\end{array}$ \\
\hline & \multirow[t]{3}{*}{ Sarlósejtes betegség, krónikus } & Rekurrens vasoocclusiv fájdalom krízis \\
\hline & & Preoperatív előkészítés \\
\hline & & Terhesség \\
\hline \multicolumn{3}{|l|}{ Leukocytapheresis } \\
\hline II. Második vonalbeli ajánlás & Hyperleukocytosis & Szimptomatikus \\
\hline III. Egyéni megítélés alapján végzett kezelés & Hyperleukocytosis & Profilaktikus vagy szekunder \\
\hline \multicolumn{3}{|l|}{ Lymphocytapheresis } \\
\hline III. Egyéni megítélés alapján végzett kezelés & Psoriasis & \\
\hline \multicolumn{3}{|l|}{ Adszorptív cytapheresis } \\
\hline II. Második vonalbeli ajánlás & Colitis ulcerosa & \\
\hline \multirow[t]{3}{*}{ III. Egyéni megítélés alapján végzett kezelés } & Colitis ulcerosa & \\
\hline & Chron-betegség & \\
\hline & Psoriasis & Disszeminált pusztulásforma \\
\hline \multicolumn{3}{|l|}{ Thrombocytapheresis } \\
\hline II. Második vonalbeli ajánlás & Thrombocytosis & Szimptomatikus \\
\hline IV. Hatástalannak vagy károsnak ítélt eljárás & Thrombocytosis & Profilaktikus vagy szekunder \\
\hline \multicolumn{3}{|l|}{ Adszorpciós granulocytapheresis } \\
\hline II. Második vonalbeli ajánlás & Vasculitis & Behçet-betegség \\
\hline \multicolumn{3}{|c|}{ Szelektív apheresisek } \\
\hline Kategória & Betegség & Indikáció \\
\hline \multicolumn{3}{|l|}{$\beta_{2}$-mikroglobulin-oszlop } \\
\hline II. Második vonalbeli ajánlás & Szisztémás amyloidosis & \\
\hline \multicolumn{3}{|l|}{ Immunadszorpció } \\
\hline \multirow[t]{3}{*}{ I. Első vonalbeli ajánlás } & \multirow[t]{2}{*}{ Vesetranszplantáció, AB0-kompatibilis } & Antitest mediálta rejekció \\
\hline & & Deszenzitizáció \\
\hline & Vesetranszplantáció, AB0-inkompatibilis & Deszenzitizáció \\
\hline \multirow[t]{3}{*}{ II. Második vonalbeli ajánlás } & Cryoglobulinaemia & Súlyos \\
\hline & Dilatatív cardiomyopathia, idiopathiás & NYHA II-IV. \\
\hline & Vesetranszplantáció, AB0-inkompatibilis & Antitest mediálta rejekció \\
\hline \multirow[t]{8}{*}{ III. Egyéni megítélés alapján végzett kezelés } & Atopiás dermatitis & \\
\hline & \multirow[t]{2}{*}{ Koagulációsfaktor-inhibitorok } & Alloantitest \\
\hline & & Autoantitest \\
\hline & Immunthrombocytaemia & Refrakter \\
\hline & Paraneoplasiás neurológiai betegségek & \\
\hline & \multirow{3}{*}{$\begin{array}{l}\text { Paraproteinaemiás demyelinisatiós neuropathia/ } \\
\text { krónikus szerzett demyelinisatiós polyneuropa- } \\
\text { thia }\end{array}$} & IgG \\
\hline & & $\operatorname{IgA}$ \\
\hline & & $\operatorname{IgM}$ \\
\hline
\end{tabular}


1. táblázat folyt.

\begin{tabular}{|c|c|c|}
\hline \multicolumn{3}{|c|}{ Szelektív apheresisek } \\
\hline Kategória & Betegség & Indikáció \\
\hline & Pemphigus vulgaris & Súlyos \\
\hline & Vesetranszplantáció, AB0-kompatibilis & Deszenzitizáció \\
\hline & $\begin{array}{l}\text { Thromboticus microangiopathia, Shiga-toxin- } \\
\text { mediált }\end{array}$ & Súlyos neurológiai tünetek \\
\hline IV. Hatástalannak vagy károsnak ítélt eljárás & Vesetranszplantáció, AB0-inkompatibilis & $\mathrm{A}_{2} / \mathrm{A}_{2} \mathrm{~B} \mathrm{~B}$-be \\
\hline \multicolumn{3}{|l|}{ Rheopheresis } \\
\hline I. Első vonalbeli ajánlás & Időskori száraz maculadegeneratio & \\
\hline III. Egyéni megítélés alapján végzett kezelés & Hirtelen sensorineuralis hallásvesztés & \\
\hline \multicolumn{3}{|l|}{ LDL-apheresis } \\
\hline I. Első vonalbeli ajánlás & Familiaris hypercholesterinaemia & Homozigóta \\
\hline \multirow[t]{4}{*}{ II. Második vonalbeli ajánlás } & Familiaris hypercholesterinaemia & Heterozigóta \\
\hline & Lipoprotein(a) hyperlipoproteinaemia & \\
\hline & Perifériás érbetegségek & \\
\hline & Refsum-betegség & \\
\hline \multirow[t]{2}{*}{ III. Egyéni megítélés alapján végzett kezelés } & Focalis segmentalis glomerulosclerosis & Szteroidrezisztencia natív vesében \\
\hline & Hirtelen sensorineuralis hallásvesztés & \\
\hline
\end{tabular}

\begin{tabular}{lll}
\hline \multirow{2}{*}{ Kategória } & \multicolumn{1}{c}{ Photopheresis } & \\
\hline I. Elsố vonalbeli ajánlás & $\begin{array}{l}\text { Cutan T-sejtes lymphoma, mycosis fungoides, } \\
\text { Sézary-szindróma }\end{array}$ & Erythrodermás \\
\hline II. Második vonalbeli ajánlás & Szívtranszplantáció & Celluláris/rekurrens rejekció \\
\cline { 2 - 3 } & & Rejekcióprofilaxis \\
\cline { 2 - 3 } & GVHD & Akut és krónikus bórérintettség \\
\hline III. Egyéni megítélés alapján végzett kezelés & Atopiás dermatitis & Bronchiolitis obliterans \\
\cline { 2 - 3 } & Cutan T-sejtes lymphoma, mycosis fungoides,, & Nem erythrodermás \\
\cline { 2 - 3 } & Sézary-szindróma & Chron-betegség \\
\cline { 2 - 3 } & Gyulladásos bélbetegségek & \\
\cline { 2 - 3 } & Nephrogen szisztémás fibrosis & \\
\cline { 2 - 3 } & Pemphigus vulgaris & \\
\cline { 2 - 3 } & Psoriasis & \\
\cline { 2 - 3 } & Scleroderma & \\
\hline IV. Hatástalannak vagy károsnak ítélt eljárás & Dermatomyositis/polymyositis & \\
\hline
\end{tabular}

AHA = Amerikai Szív Egyesület; GVHD = graft versus host betegség; HELLP-szindróma = vörösvértestek szétesésével, emelkedett májenzimszinttel és alacsony vérlemezkeszinttel járó szindróma; HBV = hepatitis B-vírus; HLA = humán leukocytaantigén; IgA = immunglobulin A; IgG = immunglobulin $\mathrm{G} ; \mathrm{IgM}=$ immunglobulin $\mathrm{M} ; \mathrm{IVIG}=$ intravénás immunglobulin; $\mathrm{LDL}=$ alacsony sű́rúségú lipoprotein; $\mathrm{MCP}=$ membránkofaktor protein; NYHA = New York-i Szívbetegséggel Foglalkozó Társaság; RhD = RhD antigén; THBD = thrombomodulin

GVHD miatti photopheresisek száma az adott öt évben 601-640-619-525-295 volt, ami nagyságrendben a Guillain-Barré-szindróma és a myasthenia gravis plasmapheresisszámait közelítette. Emellett jelentős kezelési számok vannak vese-, szív- és tüdőtranszplantátum-kilökődés esetén photo- és plasmapheresisben, valamint a hematológiai indikációjú transzplantációk miatt végzett perifériás sejtgyưjjtésben. Az adott öt évben összesen 4015 ilyen kezelés történt hazánkban.

A szisztémás autoimmun betegségek közül messze a leggyakoribb volt a szisztémás sclerosis miatt végzett photopheresisek száma, amely nagyjából azonos éven- 
\begin{tabular}{l|l} 
2. táblázat & $\begin{array}{l}\text { A magyarországi apheresiscentrumok és az általuk elvégzett ke- } \\
\text { zelések száma }\end{array}$
\end{tabular} Intézménynév Kezelésszám

Bács-Kiskun Megyei Kórház

Fejér Megyei Szent György Egyetemi Oktató Kórház

Somogy Megyei Kaposi Mór Oktató Kórház

Dél-pesti Centrumkórház - Országos Hematológiai

és Infektológiai Intézet

Jahn Ferenc Dél-pesti Kórház és Rendelőintézet

Szent János Kórház és Észak-budai Egyesített

Kórházak

Szent Imre Kórház

Uzsoki Utcai Kórház

Debreceni Egyetem, Klinikai Központ

Pécsi Tudományegyetem, Klinikai Központ

Semmelweis Egyetem, Budapest

Szegedi Tudományegyetem, Szent-Györgyi Albert Klinikai Központ

Országos Vérellátó Szolgálat

HAEMOBIL Kft.

Gyermek Múvese Alapítvány

Fresenius Medical Care

Fresenius Medical Care, Heves

Szent Margit Kórház

Szabolcs-Szatmár-Bereg Megyei Kórházak és

Egyetemi Oktatókórház

Borsod-Abaúj-Zemplén Megyei Központi Kórház és

Egyetemi Oktatókórház

\section{Photopheresis}

Dél-pesti Centrumkórház - Országos Hematológiai és Infektológiai Intézet

Debreceni Egyetem, Klinikai Központ

kénti gyakorisággal 250 és 300 között volt. Gyakorisági sorrendben a második a szisztémás autoimmun kórképek közül a szisztémás lupus erythematosus, 120-69-97152-113 éves plasmapheresis-kezelési számmal.

A vesebetegségek miatt végzett kezelések közül a gyors progressziójú nephritisszindróma a leggyakoribb, az évente kezelt betegek száma meghaladja a 100-at.

A Devic-szindróma egy viszonylag új diagnózisforma, melyben Magyarországon elfogadásra került az apheresisterápia. Az adott öt évben a kezelések száma kisebb fluktuációtól eltekintve lényeges változást nem mutat (átlagosan kb. évi 200 kezelés).

A májelégtelenség miatti kezelések száma kiugróan magas volt 2013-ban, 58 kezelés, amely lecsökkent 23-ra a következő évben. Ebben szerepet játszhat, hogy időközben bevezetésre került a májpótló kezelés (Prometheus), bár a centrumok aktivitása a kezelést illetően jelentős eltéréseket mutat.

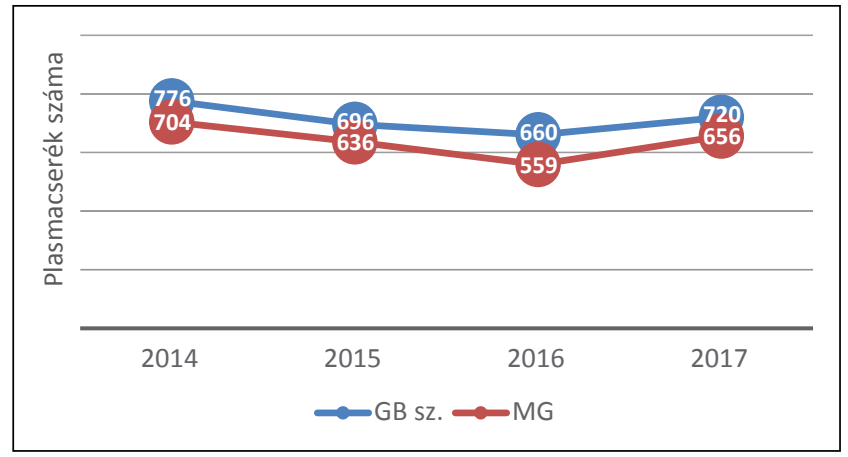

1. ábra

$$
\begin{aligned}
& \text { A myasthenia gravis és a Guillain-Barré-szindróma mi- } \\
& \text { atti kezelések éves fluktuációja } \\
& \begin{array}{l}
\text { GB sz = Guillan-Barré-szindróma; MG = myasthenia } \\
\text { gravis }
\end{array}
\end{aligned}
$$

A HELLP-szindróma miatt, a terhesség megszakítását követően végzett kezelések száma nem túl magas, de folyamatosan meglévő indikációt képez.

A gombamérgezések miatti kezelési számok a korábbi időszakhoz képest, figyelembe véve az időszak utolsó 3 évének adatait, megnyugtatóan alacsonyak. A gyógyszermérgezések miatt végzett kezelések száma is relatíve alacsony, összesen 41 kezelés történt 5 év alatt, melynek több mint fele kalciumcsatorna-blokkolók által okozott mérgezés volt.

A vizsgált ötéves periódusra esett a szelektív apheresistechnikák bevezetése Magyarországon.

Familiaris hypercholesterinaemiában alkalmazott szelektív LDL-apheresis (DALI) indult el a Debreceni Egyetemen, növekvő esetszámmal végezve a kezeléseket [8]. Magyarországon LDL-apheresis a Szent Imre Kórházban történt elsőként, ahol a mai napig kezelnek két homozigóta familiaris hypercholesterinaemiás beteget HELP-rendszerrel (heparin-induced extracorporeal lipoprotein precipitation) [9]. A 2013 és 2017 között periódusban hypercholesterinaemia esetében 141\%-os növekedés tapasztalható.

Bevezetésre került a MONET-rendszerű rheopheresiskaszkád extracorporalis eljárás, mely előzetes plasmaszeparálást követően MONET-filter segítségével távolítja el a legfontosabb, hiperviszkozitásért felelős plasmafaktorokat, azaz a fibrinogént, a trigliceridet, az alfa2makroglobulint, az IgM immunglobulinokat, továbbá az LDL-koleszterin és a von Willebrand-faktor szintje is csökken; időskori száraz maculadegeneratióban (AMD), valamint hiperviszkozitással járó diabetesesláb-szindrómában került alkalmazásra [10]. További szelektív eljárásként immunabszorpciós kezelések is történtek a Debreceni Egyetem nefrológiai, valamint angiológiai tanszékén vesetranszplantáció utáni rejekciós krízisben, valamint igazolható myocardiumellenesantitest-pozitív dilatatív cardiomyopathiában [11]. Ezen kezdeti sikerek után elindult az eljárás befogadtatása a NEAK támogatási rendszerébe. 
3. táblázat $\mid$ A kezelések száma diagnózisok szerint évenkénti lebontásban

\begin{tabular}{|c|c|c|c|c|c|}
\hline \multirow[t]{2}{*}{ Eljárás-név } & \multicolumn{5}{|c|}{ Finanszírozási év } \\
\hline & 2013 & 2014 & 2015 & 2016 & 2017 \\
\hline Septicaemia & 11 & 22 & 15 & 24 & 23 \\
\hline Hodgkin-kór & & & & 1 & 9 \\
\hline Non-Hodgkin-lymphoma & 5 & 3 & 2 & 5 & 4 \\
\hline Mycosis fungoides & & & 13 & 26 & 18 \\
\hline Sézary-kór & 211 & 236 & 221 & 239 & 198 \\
\hline Waldenström-macroglobulinaemia & 20 & 19 & 16 & 12 & 22 \\
\hline Myeloma multiplex & 86 & 69 & 93 & 96 & 75 \\
\hline Leukaemiák & 90 & 104 & 112 & 86 & 74 \\
\hline Myelodysplasiás szindróma, k.m.n. & 5 & & & & 2 \\
\hline Idült myeloproliferativ betegség & 3 & 2 & 1 & 2 & 3 \\
\hline Monoclonalis gammopathia & 18 & 5 & 5 & 10 & 2 \\
\hline Essentialis (haemorrhagiás) thrombocythaemia & 8 & 2 & 1 & 6 & 8 \\
\hline Egyéb autoimmun haemolyticus anaemiák & 17 & 30 & 9 & 18 & 11 \\
\hline Haemolyticus uraemiás szindróma & 134 & 136 & 112 & 72 & 68 \\
\hline Idiopathiás thrombocytopeniás purpura & & & & & 15 \\
\hline Essentialis thrombocytosis & 11 & 17 & 12 & 17 & 15 \\
\hline Cryoglobulinaemia & 106 & 123 & 111 & 138 & 111 \\
\hline Thyreotoxicus krízis & 3 & 7 & 5 & 5 & 13 \\
\hline Tiszta hypercholesterinaemia & 65 & 93 & 124 & 125 & 157 \\
\hline Tiszta hypertriglyceridaemia & 31 & 33 & 24 & 41 & 46 \\
\hline Kevert hyperlipidaemia & 31 & 42 & 33 & 42 & 39 \\
\hline Encephalitis, myelitis és encephalomyelitis & 33 & 84 & 100 & 41 & 22 \\
\hline Egyéb meghatározott, extrapyramidalis és mozgási rendellenességek & 6 & 11 & 8 & 3 & 14 \\
\hline Sclerosis multiplex & 39 & 27 & 45 & 35 & 20 \\
\hline A látóideg velóhüvely-gyulladása (neuromyelitis optica Devic) & 189 & 241 & 160 & 192 & 184 \\
\hline Egyéb meghatározott heveny disszeminált demyelinisatio & 113 & 58 & 118 & 93 & 75 \\
\hline Akut myelitis transversa a központi idegrendszer demyelinisatiós betegségében & & 12 & 17 & 17 & 4 \\
\hline Guillain-Barré-szindróma & 748 & 775 & 696 & 660 & 720 \\
\hline Polyneuropathiák & 301 & 391 & 397 & 425 & 560 \\
\hline Myasthenia gravis & 718 & 704 & 636 & 559 & 656 \\
\hline Myopathia k.m.n. & & & 3 & & \\
\hline Eaton-Lambert-szindróma & & 7 & & & \\
\hline Sárgafolt és hátsópólus-sorvadás & & 5 & 2 & 4 & \\
\hline Heveny és szubakut májelégtelenség & 56 & 23 & 35 & 19 & 18 \\
\hline Heveny hasnyálmirigy-gyulladás & 24 & 33 & 38 & 34 & 25 \\
\hline Pemphigus vulgaris & 31 & 16 & 8 & 10 & 30 \\
\hline Toxicus epidermalis necrolysis (Lyell) & & 7 & 2 & & \\
\hline Rheumatoid arthritis más szervek és szervrendszerek érintettségével & 9 & 4 & & 11 & 6 \\
\hline Polyarteritis nodosa & 11 & 24 & 22 & 36 & 47 \\
\hline Túlérzékenységi angiitisek & 337 & 321 & 358 & 301 & 360 \\
\hline Thromboticus microangiopathia & 283 & 444 & 388 & 352 & 321 \\
\hline Wegener-féle granulomatosis & 61 & 153 & 130 & 127 & 72 \\
\hline Nekrotizáló vasculopathia, k.m.n. & & 12 & 5 & 14 & 15 \\
\hline Szisztémás lupus erythematosus & 120 & 69 & 97 & 152 & 113 \\
\hline
\end{tabular}


3. táblázat folyt.

\begin{tabular}{|c|c|c|c|c|c|}
\hline \multirow[t]{2}{*}{ Eljárás-név } & \multicolumn{5}{|c|}{ Finanszírozási év } \\
\hline & 2013 & 2014 & 2015 & 2016 & 2017 \\
\hline Polymyositis/dermatomyositis & 16 & 3 & & 6 & 6 \\
\hline Antifoszfolipidszindróma, primer & 14 & 21 & 3 & 22 & 49 \\
\hline Akut nephritisszindróma, focalis segmentalis glomerularis laesióval & 68 & 26 & 21 & 29 & 35 \\
\hline Gyors progressziójú nephritisszindróma & 91 & 46 & 88 & 86 & 138 \\
\hline Súlyos praeeclampsia & 37 & 22 & 24 & 22 & 18 \\
\hline Abnormális plasmaviszkozitás & 11 & 9 & 10 & 2 & 14 \\
\hline Haemoglobinuria & 11 & 7 & 1 & & 5 \\
\hline Gyógyszermérgezések & 4 & 6 & 13 & 8 & 10 \\
\hline Gombák által okozott mérgezések & 18 & 9 & & & 2 \\
\hline Vesetranszplantátum-elégtelenség vagy -kilökődés & 32 & 61 & 74 & 84 & 68 \\
\hline Szívtranszplantátum-elégtelenség vagy -kilökődés & 26 & 101 & 105 & 65 & 105 \\
\hline Szív-tüdő transzplantátum elégtelenség vagy kilökődés & 2 & & 7 & & 46 \\
\hline Csontvelő-transzplantációt követő krónikus GVHD & 17 & & & & \\
\hline Csontvelő-transzplantációt követő krónikus GVHD III-IV. stádium & 584 & 640 & 619 & 525 & 295 \\
\hline Egyéb transzplantátum-elégtelenség vagy -kilökődés & 84 & 69 & 125 & 79 & 122 \\
\hline \multirow[t]{2}{*}{ Donor: csontvelö } & 535 & 469 & 489 & 594 & 669 \\
\hline & 5488 & 5859 & 5766 & 5577 & 5762 \\
\hline
\end{tabular}

GVHD = graft versus host betegség

A photopheresis-kezelés bevezetése igen nagy előrelépést jelentett a magyarországi photopheresist igénylő betegek ellátásában. A korábban Bécsben végzett kezelések átvételre kerültek, és először két magyarországi centrumban, a Szent László Kórházban és a Debreceni Egyetemen került bevezetésre egy egylépéses (online) photopheresis-rendszer, melyhez a Semmelweis Egyetem csatlakozott egy újonnan bevezetett kétlépéses (offline) rendszerrel. 2018-ban a Debreceni Egyetem is áttért a kétlépéses offline rendszerre. Az előzőekben részletezett kezelési számok mutatják, hogy a photopheresis-kezeléseknek egyre nagyobb szerepük van a klasszikus indikációk mellett (Sézary-szindróma, GVHD) a transzplantációs rejekciók kezelésében.

Jelenleg szintén nem finanszírozott még Magyarországon a CytoSorb-kezelés, amely alkalmas proinflammatoricus citokinek eltávolítására. A kezelés különösen alkalmas a citokinviharral járó állapotok kontrollálására, Magyarországon döntően a szepszis kezelésében szereztünk vele kedvező tapasztalatokat. A NEAK általi befogadása szintén folyamatban van.

\section{Megbeszélés}

A magyarországi apheresiskezelések szakmai és finanszírozási kontrollja folyamatos feladat. Az évek során az indikációs területek változnak, új indikációk jelennek meg, illetve bizonyos esetekben kiszorulnak a terápiás arzenálból. Ezért indokolt, hogy időről időre kerüljön áttekin- tésre a magyarországi centrumok múködése, az egyes indikációk számának elemzése, a változások követése. Jákó 2012-ben közölt összefoglaló tanulmánya után indokoltnak tûnt, hogy újra áttekintsük a magyarországi apheresistevékenységet. Az általa elemzett 10 év (20012010) átlagos kezelési száma 3662 apheresis/év volt, amely kezelési szám az általam elemzett 5 évben (20132017) átlagosan 5690 apheresis/év számra emelkedett. A Terápiás Aferezis Bizottság és a NEAK konzultatív együttmúködésének köszönhetően évek óta kiegyensúlyozottan biztosítják a magyarországi apheresisigényeket ebben az emelkedő számban is. A centrumok stabil müködését egy HAEMOBIL mozgó apheresishálózat egészíti ki, biztosítva ezzel Magyarország teljes lefedettségét.

Mindazonáltal a jelenleg értékelt ötéves periódusban az apheresiskeretet feszítő tényezők jelentek meg. Első helyen kell említeni az új indikációk megjelenését, melyekben Magyarország nem maradhat el a nemzetközi trendektől. Erre jó példa a Devic-szindróma mint új indikáció bevezetése, valamint a központi idegrendszert érintő demyelinisatiós indikációk elterjedése. Itt kell megemlíteni a krónikus inflammatoricus demyelinisatiós polyneuropathia (CIDP) javuló diagnosztikus lehetőségeinek kezelési számot növelő hatását.

$\mathrm{Az}$ is egyértelműen kitünik, hogy a rendelkezésre álló keretet egyre inkább feszítik a transzplantációval összefüggő plasmapheresis-, valamint a növekvő photopheresis-igények. Láthatjuk, hogy a GVHD mellett emelkedő számban történnek kezelések vese-, szív- és tüdőtransz- 
plantációs rejekciók miatt. A probléma megoldása érdekében indokolt minél hamarabbi egyeztetés az érintett társszakmákkal és a NEAK illetékeseivel.

Fontos szakmai megfontolás, hogy a magyarországi terápiás gyakorlat nem maradhat el a nemzetközi trendektől, és ez napjainkban az új szelektív technikák bevezetését és finanszírozásának megoldását jelentheti.

A jelenlegi hazai terápiás gyakorlatunkat áttekintve általánosan elmondható, hogy legnagyobb arányban neuroimmunológiai indikációval végzünk apheresiseket. Komoly és mtsai felhívták a figyelmet arra, hogy a myasthenia gravis erőteljes kombinált immunszuppresszív terápiájának bevezetése csökkenti a myastheniás krízisek kialakulásának számát, és ez potenciálisan a krízis miatt végzett kezelések csökkenéséhez vezethet [12]. Érdekes összefüggés, hogy az elmúlt öt évben a Guillain-Barrészindróma és a myasthenia gravis kezelési frekvenciája hasonló hullámzást mutat. A korábbi időszakokhoz képest a krónikus inflammatoricus demyelinisatiós polyneuropathia (CIDP) emelkedését észlelhetjük. Neurológus kollégák szerint ennek magyarázata a diagnosztikus fejlődésben áll. A neuromyelitis optica, a Devic-szindróma bekerülése a magyarországi finanszírozott rendszerbe igazolta jogosságát. Szintén indokolt a kezelés szteroidrefrakter akut disszeminált encephalomyelitisben.

A szisztémás autoimmun betegségeket tekintve letisztulási folyamat zajlott le. Szisztémás lupus erythematosusban az ajánlások a súlyos esetekre javasolják az apheresisterápiát, magára a lupus nephritis kezelésére nem. Sclerodermában a korábbi időszakkal ellentétben már nem végzünk plasmapheresis-kezeléseket, viszont jelentôsége lett a photopheresisnek. Rheumatoid arthritisben, Sjögren-szindrómában vagy például polymyositisben magának az alapbetegségnek a kezelésére nem indokolt az apheresis alkalmazása, de például társuló vasculitis jelentkezése esetén igen. Azonnali apheresiskezelés indokolt az antifoszfolipidszindróma katasztrofális formáiban.

Több évtizedes intenzív terápiás tapasztalata alapján Pénzes ismételten felhívja a figyelmet a HELLP-szindróma időben elkezdett apheresiskezelésének fontosságára [13].

A szisztémás vasculitisek egy markáns csoportját képezik az apheresisterápiának. Ebben a csoportban döntő lett az ANCA-asszociáció, első vonalban a dialízisdependens állapotokban és diffúz alveolaris haemorrhagiával. Egyéni megítélés alapján végezhetünk kezeléseket a dialízisindependens állapotokban. Goodpasture-szindrómában első vonalbeli az apheresisajánlás a dialízisindependens állapotokban, valamint a diffúz alveolaris haemorrhagia eseteiben. Ezzel szemben csak egyéni megítélés alapján végzünk kezeléseket dialízisdependens állapotokban, diffúz alveolaris haemorrhagia nélkül. Polyarteritis nodosa esetén csak $\mathrm{HBV}$-asszociált esetben van helye az apheresiskezelésnek, idiopathiás polyarteritis nodosában nem javasolható.

A microangiopathiás haemolysisek kezelési indikációjában döntő lett az ADAMTS13, illetve a H-faktor-ellenes autoantitestek kimutathatósági lehetősége. Összegezve a thromboticus microangiopathiára vonatkozó indikációkat, első vonalban van a thrombocytopeniás thromboticus purpura, a H-faktor-ellenes autoantitestes esetek, valamint a tiklopidinasszociált formák. A komplementfaktor-génmutációs esetek, a klopidogrél- és kalcineurininhibitor-asszociált esetek, valamint a Shiga-toxinmediált folyamatok kezelése egyéni megítélés alapján történik.

A fulmináns májelégtelenségek miatti kezeléseket befolyásolja, hogy idóközben Magyarországon finanszírozásra került a Prometheus májpótló kezelés is. Ezen extracorporalis kezelésekben alapvetó a transzplantációig történő bridge-terápia, de természetesen vannak transzplantációt végül nem igénylő gyógyult esetek is.

Ami a photopheresist illeti, látványos fejlődést láthatunk ma Magyarországon. A klasszikus indikáción túl, mint például a Sézary-szindróma, egyre szélesebb körben alkalmazzuk a transzplantációval kapcsolatos immunológiai problémák megoldásában. Ezek az indikációk jelentős keretfeszítő tényezőként jelennek meg napjainkban.

A transzplantációs lehetőségeket áttekintve megállapítható, hogy AB0-kompatibilis vesetranszplantáció esetén, amennyiben antitestmediált rejekció következik be, a plasmacsere és az immunadszorpció az első vonalbeli kezelés. Májtranszplantációban a plasmacsere AB0-inkompatibilitás esetén az elsődlegesen választandó deszenzitizációs terápia. Tüdőtranszplantációban, bronchiolitis obliterans jelentkezésekor photopheresist kell alkalmazni, míg ellenanyag mediálta rejekciókor egyéni megítélés alapján plasmacserét. Szívtranszplantációt követő celluláris vagy ismételt rejekció előfordulásakor photopheresis-kezelés indokolt, deszenzitizációs célból pedig plasmacsere alkalmazható.

A vizsgált öt évet áttekintve fejlődés tapasztalható a szelektív modalitások magyarországi bevezetésében is. Az LDL-apheresist követően bevezetésre került a rheopheresiskezelés is: ez a haemorrheologiai viszonyokat megjavítva olyan mikrocirkulációs javulást eredményez, mely első vonalbeli kezeléssé tette a vaksággal fenyegető időskori száraz maculadegeneratio terápiájában. Kedvező tapasztalatok vannak a diabeteses láb mikrocirkulációs szövődményeinek kezelésében is. Fokozatosan bővül a hazai klinikai tapasztalat a CytoSorb-kezelés alkalmazásával.

A nemzetközi gyakorlathoz képest elmaradás mutatkozik az immunadszorpció vonatkozásában. Ma már egyértelmú az immunadszorpció terápiás hatása a myocardiumellenes antitesttel rendelkező idiopathiás dilatatív cardiomyopathiás betegekben, cryoglobulinaemiá- 
ban, illetve a vese humoralis rejekciójában. Hazánkban már pozitív klinikai tapasztalatokkal rendelkezünk, ennek köszönhetően folyamatban van a Terápiás Aferezis Bizottság és a NEAK együttmúködésében a finanszírozási háttér kialakítása.

Anyagi támogatás: A közlemény megírása, illetve a kapcsolódó kutatómunka anyagi támogatásban nem részesült.

A szerző a cikk végleges változatát elolvasta és jóváhagyta.

Érdekeltségek: A szerzőnek nincsenek érdekeltségei.

\section{Köszönetnyilvánítás}

Az anyag összeállításában köszönet illeti a Terápiás Aferezis Bizottság tagjait és a NEAK Speciális Finanszírozási Főosztály vezetőjét, $d r$ Gerendy Pétert, a szakmai és finanszírozási statisztikai adatok elemzésében nyújtott segítségükért.

\section{Irodalom}

[1] Schwartz J, Padmanabhan A, Aqui N, et al. Guidelines on the use of therapeutic apheresis in clinical practice-evidence-based approach from the Writing Committee of the American Society for Apheresis: the seventh special issue. J Clin Apheresis 2016; 31: 149-162.

[2] Belák M, Jákó J. National survey of hemapheresis practice in Hungary 2001-2004. Ther Apher Dial. 2007; 11: 22-29.

[3] Jákó J. The past, present and possible future of plasmapheresis in Hungary. [Az aferezis hazai múltja, jelene és lehetséges jövője.] Focus Med 2012; 14(2-3): 3-15. [Hungarian]

[4] Domján G, Gadó K. Adulthood indications of plasmapheresis [A plazmaferezis felnőttkori indikációi.] Focus Med 2012; 14(2-3): 18-24. [Hungarian]
[5] Túri S, Bereczki Cs, Haszon I, el al. Therapeutical apheresis in childhood. [Terápiás aferezis gyermekkorban.] Focus Med 2012; 14(2-3): 25-31. [Hungarian]

[6] Réti M. Thrombotic thrombocytopenic purpura and hemolyticuremic syndrome. [A thromboticus thrombocytopeniás purpura és haemolyticus uraemiás szindróma.] Focus Med 2012; 14(2-3): 38-46. [Hungarian]

[7] Soltész P, Bedő Z, Veres K, et al. Plasmapheresis therapy on the 3rd clinic for internal medicine of DEOEC in the last 30 years. [Plazmaferezis terápia a Debreceni Egyetem III. számú Belklinikáján az elmúlt 30 évben.] Focus Med 2012; 14(2-3): 3236. [Hungarian]

[8] Harangi M, Zsíros N, Balla J, et al. Our experiences with the procedure of the selective low-density lipoprotein apheresis treatment. [Tapasztalataink a szelektív LDL-aferezis kezeléssel.] Metabolizmus 2014; 12: 19-23. [Hungarian]

[9] Kerkovits L, Kiss I, Szamosi T, et al. H.E.L.P. treatment, as a non pharmacological therapy of hypercholesterolaemia - one a half year experience in Hungary. Proceedings of the International Congress on Prevention of Atherosclerosis in Childhood. Budapest, 1997; pp. 42-48.

[10] Vass M, Diószegi Á, Németh N, et al. Rheopheresis in vascular diseases. Clin Hemorheol Microcirc. 2016; 64: 977-987.

[11] Soltész P, Vass M, Diószegi Á, et al. Immunoadsorption in a patient with dilated cardiomyopathy. The first case in Hungary. [Dilatatív cardiomyopathia immunadszorpciós kezelése. Az első magyarországi eset kapcsán.] Orv Hetil. 2018; 159: 526-530. [Hungarian]

[12] Rózsa C, Mikor A, Kasa K, et al. Long-term effects of combined immunosuppressive treatment on myasthenic crisis. Eur J Neurol. 2009; 16: 796-800.

[13] Mezödy M, Diószeghy C, Pénzes I. HELLP syndrome, an unusual form of pregnancy toxicosis. [A HELLP-szindróma, mint a terhességi toxikózis egyik nem megszokott formája.] Orv Hetil. 1995; 136: 2733-2736. [Hungarian]

(Soltész Pál dr.,

Debrecen, Móricz Zsigmond krt. 22., 4032 e-mail: dr.soltesz.pal@gmail.com)

Az Orvosi Hetilap 2019; 160: 560. oldalán (14. szám) megjelent OH-Kvízre két helyes megfejtés érkezett.

A beküldők: Dr. Bíró László (Budapest) és Dr. Janik Leonárd (Budapest). A nyerteseknek szívböl gratulálunk.

A nyereményüket - egy, az Akadémiai Kiadó webáruházában kedvezményes vásárlásra jogosító kupont - e-mailen küldjük el.

A cikk a Creative Commons Attribution 4.0 International License (https://creativecommons.org/licenses/by/4.0/) feltételei szerint publikált Open Access közlemény, melynek szellemében a cikk bármilyen médiumban szabadon felhasználható, megosztható és újraközölhető, feltéve, hogy az eredeti szerző és a közlés helye, illetve a CC License linkje és az esetlegesen végrehajtott módosítások feltüntetésre kerülnek. (SID_1) 